\title{
REPORT OF AN EXCURSION TO THE CUCKMERE VALLEY AND SEAFORD.
}

\author{
JULY 26TH, I9I3.
}

By J. Vincent Elsden, D.Sc., F.G.S., Director of the Excursion.

ON Saturday, July 26, a party of about a dozen travelled to Newhaven for the purpose of examining the inland outcrop of the Marsupites zone and other features in the district lying between the Ouse and the Cuckmere rivers. Ascending the Downs at Mount Pleasant, where the junction of the zones of Marsupites and Actinocamax quadratus is to be seen in small pits near the top of the hill, a visit was first made to Bishopstone village by following the ridge skirting the deep dry valley in which lies the pumping station of the Newhaven and Seaford waterworks. On arriving at Bishopstone a visit was made to the Church, where Mr. G. J. B. Fox kindly explained the chief architectural features and pointed out the successive additions which had been made to the original structure, which dates from Saxon times. The surface here is composed of Actinocamax quadratus chalk, and specimens of Cardiaster pilluta were obtained in a small exposure close to the village, but the junction of the Marsupites zone is not far away, this zone underlying all the ploughed land in the valley bottom north of the village. The party then proceeded towards Hindover, following the southern edge of the deep dry valley of Hobb's Hawth. The junction of the Marsupites zone lies just below this ridge, the strike running east and west, but there are few exposures. A pipe in Actinocamax Chalk near the golf links is filled with Tertiary sand. The valley debouches into the Cuckmere valley below Hindover in a markedly constricted and sinuous opening. Similar constrictions occur as a general feature at the junctions of most of the dry valleys in this area, the narrow openings bearing no proportion to the wide and open character of the higher portions of the valleys. No satisfactory explanation of this feature was forthcoming, and this phenomenon deserves the attention of workers in chalk physiography.

At Alfriston a short halt was made for lunch, and the party was here reinforced by several additions to its number. A start was then made for the ascent of Hindover Hill. Leaving the road, they attacked the steep face of the hill, and the Director pointed out that the base of the hill was in the Micraster cor-anguinum zone, near the top of which was a Conulus band, after which the Uintacrinus sub-zone appears, 
EXCURSION TO THE CUCKMERE VALLEY AND SEAFORD. 28 I

passing into the Marsupites sub-zone, which outcrops below the summit. Specimens of the zone fossil were duly found at the spots indicated by the Director. The upper part of the hill is in the Actinocamax quadratus zone, the whole of the beds dipping into the hill towards the south.

From the top of the hill the surface falls along a dip slope towards Chyngton Farm, to which a visit was next made. The whole of the ground is in the Actinocamax quadratus zone, and at the farm an Eocene outlier was examined. Here the whole thickness of the Actinocamax quadratus zone is present, the Marsupites zone being deeply buried below sea-level, whereas at Hindover it was last seen $200 \mathrm{ft}$. above sea-level. Chyngton Farm lies at the head of a true synclinal valley extending to Seaford, its western end being drowned in the Channel. The preservation of numerous Eocene outliers along this valley is probably due to this synclinal structure.

Seaford Head marks the southern limb of this fold. The beds here dip northwards, and the strike of the Marsupites zone can only be directly traced in the sea cliff near the stone groyne at Seaford Head, but its direction can be inferred from the strike of the Actinocamax quadratus zone along the summit of the Head. The party examined this question by the study of an exposure in a critical position below Chyngton Barn, where Cardiaster pillula was found in an old chalk pit north of the Barn and close by it. The outcrop of the Marsupites zone itself is obscured along the northern face of Seaford Head, where there is much gravel on the higher parts. The origin of this gravel is uncertain, but it may be part of an old terrace gravel of the Cuckmere upturned on the limo of the fold. It is interesting to note that there is no such gravel capping on the opposite side of the Cuckmere at Seven Sisters, where it can be shown that there is no indication of the Seaford fold.

The Seaford syncline, with its counter dip slopes, is a unique feature of this area, and the Director pointed out that the detection of this structure was due entirely to zonal mapping, for which purpose Marsupites and Uintacrinus have advantages unequalled by any other zone fossils in this area.

The evidence upon which is based the existence of a fault in the Cuckmere valley was then explained by contrasting the deep synclinal depression at Seaford with the nearly flat arrangement of the beds on the opposite side of the valley, where the Marsupites zone forms the surface of the higher ground between Friston and the Seven Sisters. The Marsupites zone here forms a plateau, the base of the zone being everywhere about $100 \mathrm{ft}$. or so above sea-level, whereas at Chyngton, just below the valley, it is some $200 \mathrm{ft}$. below sea-level.

At Chyngton some of the party followed the Director towards the Cuckmere to gain a view of the river mouth, and it was 
pointed out how variable the river channel is, being sometimes completely closed by shingle banks, so that it can be crossed dryshod. An interesting example is shown in the accompanying sketches, Fig. 22, taken respectively in the years 1909 and 1912. A spit some hundred yards long had, in the meantime, been
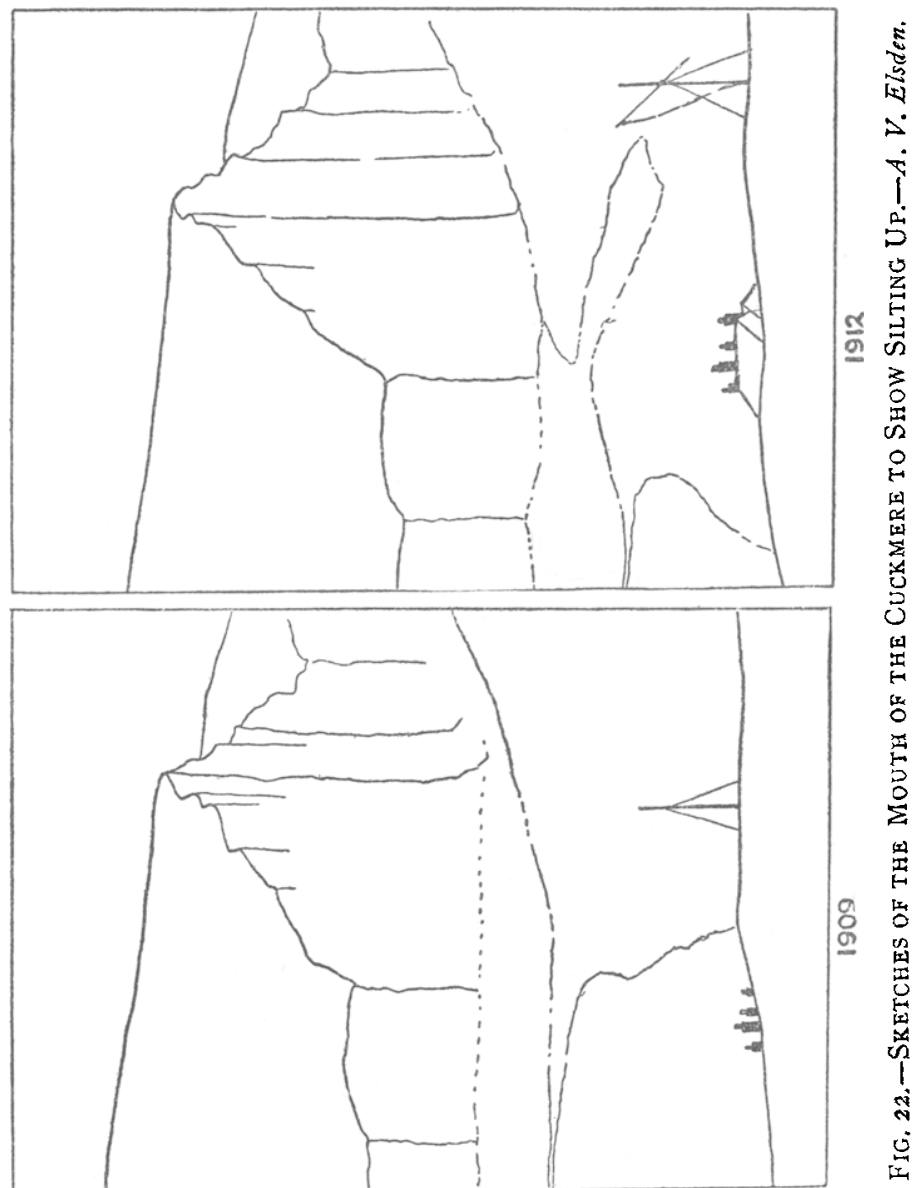

thrown out seawards. Last year this spit was removed by a violent storm in the spring, when the sea filled the whole valley as far as Exceat Bridge. The Cuckmere has reached the base level of denudation, and only in seasons of flood is it able to maintain its connection with the sea. The sketches show also the rift-like character of the Cuckmere estuary.

The party now descended Seaford Head and proceeded to the 
Verandah Tea Rooms at Seaford for tea. The return journey to London was made by the 7.30 train from Seaford. The weather was delightful throughout the day, and, thanks to the excellent arrangements made by Miss Cadmore, who acted as Excursion Secretary, a somewhat heavy programme was successfully accomplished.

\title{
REPORT OF A VISIT TO THE CEYLON AND MALAY PENINSULA COURTS OF THE IMPERIAL INSTITUTE.
}

\section{February 14TH, I9I4.}

\author{
By J. W. Evans, LL.B., D.Sc., F.G.S.
}

THE party, some twenty-five in number, were met by Dr. Evans at the eastern entrance, and when the Ceylon Court was reached he gave a brief account of the geology of the island.

With the exception of the comparatively unimportant Quaternary deposits, the whole of the rocks appear to be of vast antiquity. Some are apparently igneous rocks formed at a considerable depth below the surface, while others, which contain such minerals as sillimanite, may, although highly crystalline in structure, be the metamorphosed representatives of sedimentary strata. It is, on the other hand, very difficult to come to any definite conclusion as to the mode of formation of the bands of dolomitic marble which may often be followed for a considerable distance.

Among the more important mineral products of Ceylon are the gem-stones, which are obtained from the river gravels, though their ultimate source was no doubt in the limestone. Almost every species of gem is represented, the most important exception being the diamond.

With the gems are found a number of minerals containing rare or uncommon elements, including cerium and its allies, thorium and uranium, the two last being of value on account of their radio-active character. One of these minerals is thorianite, which consists of oxide of thorium with a certain proportion of the oxides of uranium, iron, calcium and lead. It crystallizes in cubes which are frequently twinned in a manner closely resembling the twinning of fluor-spar.

The uranium is always accompanied in this and other minerals by lead, and it is supposed that the latter is produced by the slow breaking up of the former. Calculating on this hypothesis, Mr. Arthur Holmes has deduced an age of about 